Вісник Дніпропетровського університету. Серія: геологія, географія. 24 (2), 2016, 114-120.

Vìsnik Dnìpropetrovs'kogo unìversitetu. Serî̀ Geologîa, geographìâ

Dnipropetrovsk University Bulletin. Series: geology, geography. 24 (2), 2016, 114-120.

Doi: $10.15421 / 111639$

http://geology-dnu.dp.ua

УДК 911.52:[910.2+004.9]

\title{
Ландшафтна структура проектованого національного природного парку «Орільський» у межах Петриківського району Дніпропетровської області
}

\section{О. В. Сизенко}

\author{
Дніпропетровський національний університет імені Олеся Гончара, Дніпро, Україна, е-таil: ehsyzenko@, \\ gmail.com
}

\begin{abstract}
Мета публікації - аналіз та узагальнення досвіду досліджень ландшафтного різноманіття проектованого національного парку «Орільський» у межах Петриківського району Дніпропетровської області. Охарактеризовано вихідні передумови щодо історії ландшафтознавчих досліджень у регіоні. Надано комплексну фізико-географічну характеристику природного комплексу національного природного парку «Орільський». Здійснено маршрутні польові дослідження для встановлення головних рис морфологічного різноманіття ландшафтів у межах усієї території парку, а також здійснено серію напівстаціонарних ландшафтних та геоботанічних описів на більш типових ділянках, виділених як ключові для подальшого вивчення ландшафтного різноманіття долини р. Оріль. На стадії польових досліджень виділено окремі ландшафтні одиниці та їх геопросторові межі. Проведено картографування ландшафтного різноманіття та проаналізовано отримані результати. Дослідження виявило, що сучасне ландшафтне різноманіття Петриківського району сформоване переважно антропогенними, а, отже, енергетично залежними від господарських циклів типами ландшафтів, що безумовно негативно впливає на загальний стан суміжних природних та напівприродних комплексів. Виділено одинадцять ландшафтних типів у межах досліджуваної території. Одержані результати репрезентують внутрішні відмінності в межах району, з урахуванням яких можна розробити оптимальну структуру природокористування в межах досліджуваної території, зберегти і збільшити його ландшафтну різноманітність.
\end{abstract}

Ключові слова: ландшафтна структура, національний природний парк, Оріль, Петриківський район

\section{Landscape structure of projected national park «Orilskyy» within Petrykivsky district of Dnipropetrovsk region}

\section{O.V. Syzenko}

Oles Honchar Dnipropetrovsk National University,Dnipro,Ukraine,olehsyzenko@gmail.com

The purpose of this study is to analyze and summarize the experience of landscape diversity research within Petrykivsky district of projected national park "Orilskyy". Scientific substantiation of creating a national park "Orilskyy" in the Dnipropetrovsk region prepared to order the Department of Environment and Natural Resources of the Dnipropetrovsk Regional State Administration. Due to the remoteness from major industrial centers Oril River can be considered one of the cleanest and least transformed steppe river. Its valley preserved typical and unique landscape complexes in dire need of protection because of the tense ecological situation in the region. Initial assumptions concerning the history of landscape studies of the region are characterized. Comprehensive description of the natural territorial complex national park "Orilskyy" within Petrykivsky regionis outlined. Route field research to establish the main features of the morphological diversity of landscapes within the entire territory of the planned national park, and also a series of semi-stationary landscape and geo-botanical descriptions of more typical areas highlighted as key were carried out. In the field stage of research, the verification of selected landscape units and their geospatial boundaries was carried out. Landscape diversity within studied area is defined and mapped. As an indicator in the allocation of individual landscape units were used characteristics of the earth's surface - uniform topography and lithological composition of the rocks of the aeration zone, and the same type of vegetation that points to a common origin of selected units. The study found that modern landscape diversity of Petrikivsky district was formed mostly with man-made, and thus energy-dependent types of landscapes that certainly adversely affects the general condition of natural and related systems. Eleven landscape types were allocated within studied area. All variety of selected landscape units can be divided into two groups. The first group includes natural and semi-natural landscapes, presented within the floodplain and the first terrace of Oril valley. The second large group includes man-made landscapes, which are largely dependent from the man because of disability of keeping environmental sustainability and energy-dependence. Developed maps illustrate in detail the nature of the landscape differentiation and can serve as a basis for future more detailed facies mapping, used as a basis for all future research in the area of the park, as well as for the development and implementation of environmental policies and programs, tourism 
management, etc. The results represent the internal differences within the area that will develop the optimal structure of nature within the study area, maintain and increase its landscape diversity.

Keywords: landscape structure, national park, Oril, Petrykivsky district.

Постановка проблеми та ії актуальність. Протягом останніх трьох десятиріч учені-натуралісти наголошують на необхідності створення національного природного парку в межах долини $\mathrm{p}$. Оріль. Завдяки віддаленості від великих промислових центрів їі можна вважати однією з найчистіших та найменше трансформованих річок степового Подніпров'я. В їі долині збережені типові та унікальні ландшафтні комплекси, що вкрай потребують охорони, зважаючи на напружений екологічний стан у регіоні. Збереження ландшафтного різноманіття розглядається як одна із складових комплексної охорони Приорілля, на рівні із збереженням біотичного різноманіття та історико-культурної спадщини. Саме тому комплексні ландшафтознавчі дослідження долини р. Оріль вкрай актуальні для степового Подніпров'я.

Зв'язок із важливими науковими та практичними завданнями. Наукове обгрунтування створення національного природного парку «Орільський» в Дніпропетровській області підготовлене на замовлення департаменту екології та природних ресурсів облдержадміністрації. Авторський колектив складався 314 провідних науковців та спеціалістів регіону з відповідною фаховою спеціалізацією. Крім того, до виконання проекту приєдналися ще 19 учених та спеціалістів, котрі на громадських засадах виконали певні розділи чи підрозділи проекту або ж надали цінний авторський матеріал, зібраний ними на території басейну р. Оріль і котрий має пряме відношення до питань проектування національного природного парку в цій місцевості.

Вихідні передумови. Ландшафтознавчі дослідження території Дніпропетровської області починалися з робіт Т. А. Клевцова і П. Ф. Калініної, що були проведені на основі ландшафтно-генетичного підходу наприкінці 1950-х років [Kalinina P. F., Chugaj N. S., Bashmakov I. P., Malashenko T. D., 1971; Klevtsov T. A., 1960]. Ще раніше геоботаніки О. Л. Бельгард [Belhard A. L., 1940] та О. А. Єліашевич [Yeliashevych O. А., 1937] детально охарактеризували окремі найпоширеніші природні комплекси Приорілля. Ландшафтне районування території Дніпровсько-Орільського природного заповідника запропонував C. В. Шуйдін [Shujdin S.V., 1998], наголошуючи на корисності ландшафтної карти як основи для функціонального зонування природоохоронних територій. Окремі компоненти природно-територіальних комплексів Приорілля детально характеризуються в матеріалах науково-практичного семінару «Проблеми створення Орільського національного природного парку» за авторством Б. О. Барановського, В. В. Дем'янова, В. М. Кочет, В. В. Манюка, П. Т. Чегорки та ін. [Baranovskyi B. O., 2013; Demianov V. V., 2000; Maniuk V. V., 2000].

У 2003 році в долині р. Оріль працювала експедиція еколого-натуралістичного об'єднання «Орлан» [Chehorka Р. Т., 2003]; значну кількість публікацій про флору, фауну та ландшафти Приорілля можна знайти в альманаху «Свята справа», що ним видається [Domrachev V., 2001]. Детальне зонування та оцінку ландшафтно-функціональної структури проектованого національного парку в межах Шульгівської сільради виконали працівники кафедри фізичної та економічної географії Дніпропетровського національного університету імені Олеся Гончара [Zelenska L. I., Afanasiev O. Y., Maniuk V. V., Solohub T. P., 2009]. Завершальним етапом наукового обгрунтування природної цінності досліджуваної території було видання проекту створення національного природного парку «Орільський» у 6 томах за редакцією В. В. Манюка.

Мета і завдання. Мета публікації - виклад підсумків експедиційних ландшафтознавчих досліджень у басейні р. Оріль в межах Петриківського району Дніпропетровської області. Для реалізації поставленої мети необхідно виконати низку завдань, а саме: 1. Охарактеризувати вихідні передумови дослідження та ступінь вивченості об'єкта. 2. Визначити методику виділення ландшафтних одиниць, їх ієрархію та місце в загальній схемі класифікації ландшафтів. 3. Провести картографування ландшафтного різноманіття та проаналізувати отримані результати.

Виклад основного матеріалу. Проектований національний природний парк «Орільський» розташований у басейні р. Оріль - лівої притоки р. Дніпро, зокрема, у тій частині басейну р. Оріль, що згідно з адміністративно-територіальним устроєм України належить до Дніпропетровської області. Річка Оріль протікає в межах Дніпропетровської області по території п'яти адміністративних районів, за напрямком течії річки це - Юр'ївський, Новомосковський, Магдалинівський, Царичанський і Петриківський райони. Конфігурація те- 
риторії парку в цілому повторює контури долини р. Оріль, з довгими відгалуженнями, які відходять від долини в бік Орільсько-Самарського та Орільсько-Дніпровського вододілу по вузьких долинах лівобережних річок і балок - приток р. Оріль. На межі Петриківського i Царичанського районів орільська долина накладається на дніпровську, котра має в цьому місці надзвичайно велику ширину - до 22 км.

Територія Орільського національного природного парку, зважаючи на значні розміри і протяжність, а також прикордонне розташування долини р. Оріль неподалік від межі Лісостепу і Степу, охоплює чотири фізико-географічні райони Орільсько-Самарської низовинної області Лівобережнодніпровсько-Приазовського краю Північностепової підзони Степової зони України. За течією р. Оріль від північно-східної до південно-західної межі парку райони змінюються в такому порядку: Кегичівсько-Сахновщинський, Нижньотернівський, Магдалинівсько-Перещепинський та Нижньоорільсько-Дніпровський. Неподалік північного краю території національного парку, по умовній лінії, що розділяє долину р. Оріль і вододіл, по Харківській і Полтавській області проходить межа між Магдалинівсько-Перещепинським i Зачепилівсько-Красноградським фізико-географічними районами. У південній частині територія національного парку через Дніпро (точніше, через акваторію Дніпродзержинського водосховища) межує з Верхівцевсько-Солонівським та Павлисько-Верхньодніпровським районами Південно-Придніпровської схилово-височинної області, яка належить до Дністровсько-Дніпровського краю північностепової підзони (фізико-географічне районування України, прийняте у Національному атласі України, автори О. М. Маринич, Г. О. Пархоменко та ін.).

Орільський національний природний парк важливе природне ядро екомережі національного значення, розташоване на перехресті двох найважливіших транснаціональних екокоридорів Пан'євройпейської екомережі - Дніпровського меридіонального й Українського степового широтного, а також є головною частиною міжрегіональної сполучної території між лівобережним Наддінпрянським Лісостепом та Степом та між басейнами Дніпра і Сіверського Дінця.

Протягом квітня - жовтня 2015 р. здійснено маршрутні польові дослідження для встановлення головних рис морфологічного різноманіття ландшафтів у межах усієї території проектованого на- ціонального природного парку, а також здійснено серію напівстаціонарних ландшафтних та геоботанічних описів на більш типових ділянках, виділених як ключові для подальшого вивчення ландшафтного різноманіття долини р. Оріль.

Відсутність попереднього досвіду ландшафтних досліджень окремих локальних геосистем чи їх компонентів, а також маршрутний метод польових досліджень ставить ландшафтознавця перед складним завданням виділення та систематики ландшафтних одиниць найнижчого рангу. Вирішенням цієї проблеми може бути ландшафтний синтез на основі індикаторних критеріїв геосистем. Як індикаторні фактори для виділення окремих ландшафтних одиниць були використані характерні особливості денної поверхні - однорідні рельєф та літологічний склад порід зони аерації, а також однаковий тип рослинності, що вказує на спільність походження виділених одиниць. Вихідним матеріалом для картографування слугували космічні знімки досліджуваної території, наявні в базах вільного доступу картографічних сервісів Google Earth та Bing Maps (джерело - Digital Globe), а також окремі аркуші топографічної карти України масштабу 1 : 25000 і 1 : 50 000. Додаткову інформацію стосовно просторової диференціації окремих природних компонентів у межах досліджуваної території отримано із серії тематичних карт Національного атласу України. На польовому етапі дослідження проведено верифікацію виділених ландшафтних одиниць та їх геопросторових меж. За результатами складено ландшафтну карту території Орільського національного природного парку на топографічній основі масштабу 1: 50000.

Територія проектованого Орільського національного природного парку в межах Петриківського району Дніпропетровської області згідно 3 фізико-географічним районуванням України за характером ландшафтно-типологічної структури входить до Нижньоорільсько-Дніпровського району Орільсько-Самарської низовинної області Лівобережнодніпровсько-Приазовського краю Північностепової підзони Степової зони України.

Зональними ландшафтами для Петриківського району є лесові низовини, з чорноземами звичайними середньогумусними, під різнотравно-типчаково-ковиловою рослинністю. У ландшафтному відношенні територія національного природного парку належить до азонального типу ландшафтів, що включає в себе набір динамічно пов'язаних між собою долинних урочищ басейну р. Оріль. Вона охоплює ділянку долини від місця розхо- 
дження річки на нове та старе русло, $\mathrm{i}$ до берегів водосховища. Долина тут значно розширюється i Оріль протікає через алювіальні голоценові тераси Дніпра. Тому цю ділянку можна вважати довгозаплавно-аренним природним комплексом. Диференціація долини на першу (заплавну), другу (аренну) і солончакову тераси чітко простежується по всій їі довжині. В заплаві більш-менш чітко розрізняються три зони - прируслова, центральна і притерасна. В заплаві і на третій терасі набирають сили болотний і алювіальний процеси, арена сильно розвинута.

Згідно з Національним атласом України, територія проектованого національного парку в межах Петриківського району включає два типи природних ландшафтів: степові ландшафти та заплавні ландшафти рівнин. Основна частина парку в межиріччі нового русла р. Оріль та Дніпродзержинського водосховища належить до піщаних терас iз дерновими грунтами у поєднанні 3 лучними солонцюватими, острівними борами і суборами. Вздовж лівого берега р Оріль тягнеться смужка плавнів, лучно-степових солонцювато-солончакуватих заплав. Крайня північно-східна частина парку належить до лесових терас із чорноземами звичайними середньогумусними у поєднанні 3 лучно-чорноземними солонцюватими грунтами $i$ солонцями, у минулому під різнотравно-типчаково-ковиловою рослинністю.

Проведене дослідження виявило, що сучасне ландшафтне різноманіття Петриківського району сформоване переважно антропогенними, а, отже, енергетично залежними від господарських циклів типами ландшафтів, що безумовно негативно впливає на загальний стан суміжних природних та напівприродних комплексів.

Усе різноманіття виділених ландшафтних одиниць можна умовно поділити на дві групи. Перша група ландшафтів включає в себе природні на напівприродні ландшафти, представлені в межах Петриківського району долинними типами в межах заплави та першої надзаплавної тераси р. Оріль. Ландшафти даного типу сформувалися на алювіальних відкладах та чорноземах лучних та солонцюватих (рис.).

Фоновими для долинного типу ландшафтами в межах Петриківського району виступають справжні та галофільні заплавно-лучні ландшафти, що рівномірно поширені на досліджуваній території. Для лівобережжя старого русла р. Оріль характерні справжні луки, для решти територій переважно галофільні зі значним ступенем засо- лення. Справжньолучні ландшафти сформувалися на виположених ділянках заплави. Це переважно свіжі і вологі зонтично-різнотравні та пирійно-різнотравні луки на осолоділих лучних, у комплексі 3 лучно-чорноземними супіщаними, грунтах на стародавньому алювії. На підвищених ділянках серед лук трапляються куртини степових чагарників. На вирівняних, знижених просторах притерасної заплави вздовж нового русла р. Оріль формуються галофільні луки, солонці і солончаки, очеретові болота. Остепнені галофільні луки часто використовуються під сіножаті, деякі з них поліпшені або розорані, із штучно створеним бобово-злаковим травостоєм. На тлі водойм і боліт у заплаві окремими масивами виділяються дібровно-лучні комплекси. Окремими ареалами в межах заплави представлені болотні ландшафти, проте їх площі незначні.

Особливістю відрізка Орільської долини в Петриківському районі є останці аренної піщаної тераси, де формуються псамофільно-степові ландшафти на слабогривистому або дюнному рельєфі 3 характерною для дніпровсько-самарсько-орільських піщаних терас рослинністю на ділянках відкритої піщаної арени, що найбільше поширені в районі с. Шульгівка та Єлизаветівка. Незначні ареали пісків тягнуться вузькою смужкою вздовж узбережжя Дніпродзержинського водосховища, чергуючись із штучно залісненими ділянками.

Лісові ландшафтні типи представлені середньо- та короткозаплавними дібровами та акацієвими насадженнями із сосною. Діброви не мають суцільного поширення, а трапляються окремими, інколи значними масивами. Природні діброви поширені по заплаві старого русла р. Оріль. 3-поміж них переважають середньозаплавні берестові та в'язо-берестові діброви, інколи з домішкою клена гостролистого. На підвищених елементах рельєфу, особливо ближче до розходження р. Оріль на нове і старе русло, формуються класичні в'язо-чорнокленові діброви. Досить звичайні в гирловій частині вологі осокорники і вербняки. Решта листяних лісових комплексів представлена напівприродними акацієвими насадженнями 3 незначними домішками інших порід. Такі насадження утворюють фрагментований ареал у районі с. Радсело та Куліші. Борові лісові ландшафти зустрічаються на алювіальних аренах у районі Шульгівки та вздовж Дніпродзержинського водосховища. Практично всі соснові ліси штучно створені, але, враховуючи екологічні умови їх зростання та структуру рослинного покриву, ці ліси можливо віднести за ти- 


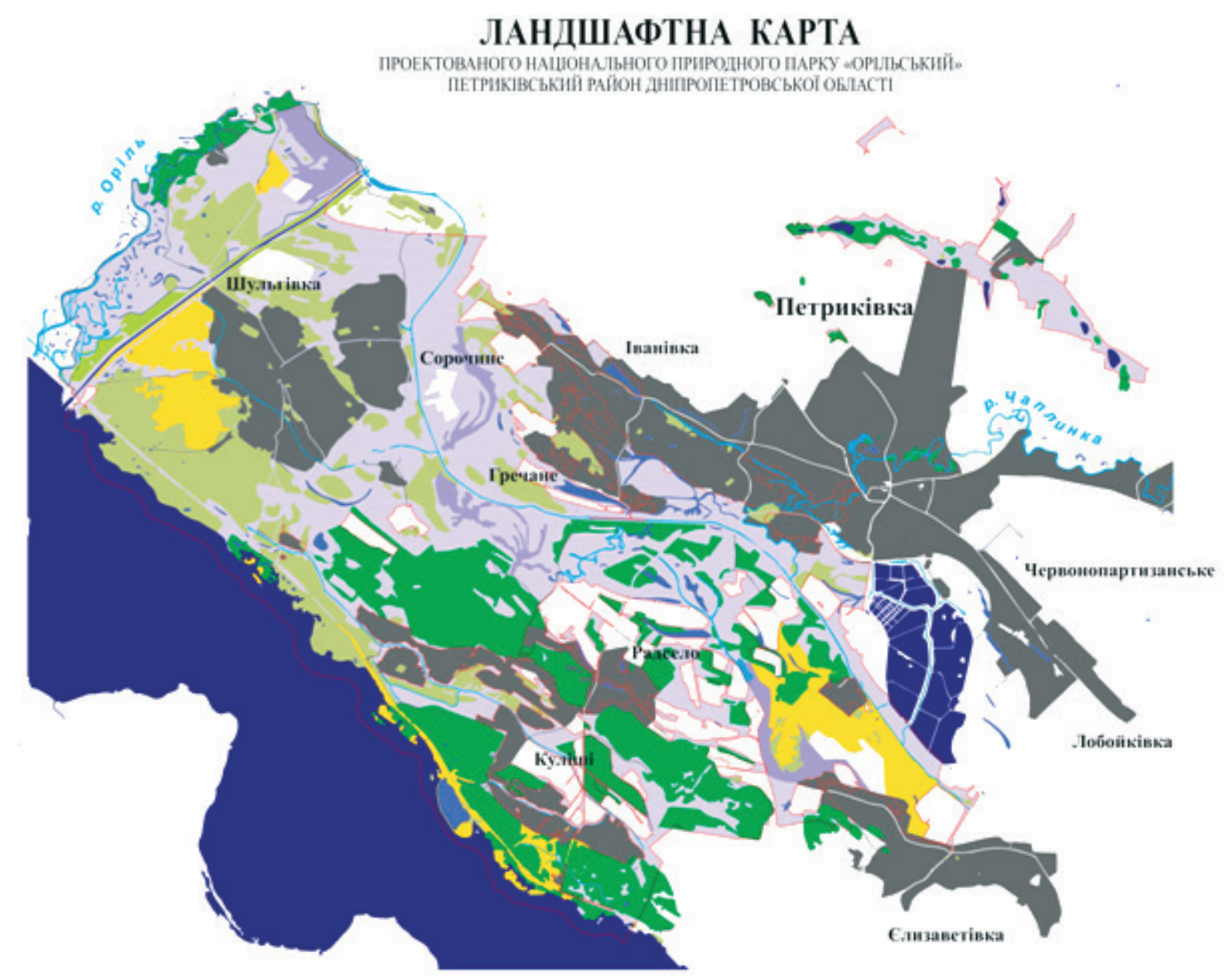

\section{ЛАНДШАФТИ}

\section{ПРИРОДНІ}

\section{Долинні}

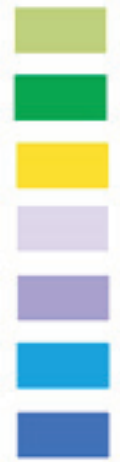

лісові борові

лісові листяні

псамофільно-степові

заплавно-лучні

болотні

аквальні руслові та руслово-озерні

аквальні озерні (лиманні)

\section{АНТРОПОГЕННI}

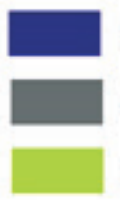

аквальні штучні

селитебні

захисні лісосмуги

орні агроландшафти

Іванівка населені пункти

n............

Рис. Ландшафтна карта проектованого національного природного парку «Орільський» у межах Петриківського району Дніпропетровської області

пологією О. Л. Бельгарда до аренних позазаплавних.

Природні аквальні ландшафти долини являють собою русло Орілі та іiі руслові озера, а також характерні для національного парку лимани.
Проте варто зазначити, що порівняно з іншими адміністративними районами для Петриківського району характерна значно менша кількість озер. Поширені вони переважно в пригирловій ділянці старого русла Орілі, в межах заплави. В межах 
кожної дуги меандрування річка утворює безліч петель, дуг, кілець і проток, котрі під час повеней 3'єднуються і часто утворюють суцільні широкі плеса. У межах Петриківського району розташовані притоки Орілі річки Цеглянка, Лобойківська Проточ, Стара Проточ, Чаплинка, Судовка, Клешнівка, безстічне урочище Підкряжне (Низівське). Річка Стара Оріль протікає частково по межі Петриківського і Царичанського, частково - Петриківського i Кобеляцького районів (Полтавська обл.).

Друга велика група ландшафтів включає в себе антропогенні ландшафти, що значною мірою залежні від людини, оскільки не здатні самостійно зберігати екологічну та енергетичну стійкість. Фоновим ландшафтним типом 3-поміж антропогенних $є$ орні агроландшафти на місці різнотравно-типчаково-ковилових степів. До категорії агроландшафтів також можна віднести захисні лісосмуги з дуба, акації, кленів, ясенів, що тягнуться переривчастою смугою 10 - 20 м шириною уздовж каналу Дніпро - Донбас майже по всій його протяжності. Вони переважно в незадовільному або пригніченому стані.

Селитебні ландшафти утворюють дві смуги: перша - населені пункти Іванівка, Петриківка, Червонопартизанське та Лобойківка - розташована вздовж північного кордону парку; друга Шульгівка, Сорочине, Радсело, Куліші, Слизаветівка - проходить по центральній його частині. Значна частка приорільських сіл заслуговує інтеграції до території національного парку, оскільки вони являють собою невід'ємну складову унікальних природно-культурних ландшафтів, мають високу етнокультурну, ландшафтно-естетичну та історико-культурну цінність.

Аквальні штучні типи ландшафтів представлені великими ставками в районі с. Лобойківка, Дніпродзержинським водосховищем, а також каналом Дніпро - Донбас, що тягнеться південніше від старого русла Орілі. Канал, що прокладено по долині р. Оріль, разом зі всіма допоміжними дренажними каналами, валами, захисними смугами є невід’ємною частиною складного природно-антропогенного ландшафтного комплексу, який сформувався на сьогодні в долині р. Оріль.

Висновки. В результаті дослідження ландшафтної різноманітності території проектованого Орільського національного природного парку в межах Петриківського району Дніпропетровської області виділено 11 ландшафтних типів. Підтверджено необхідність створення у Прио- ріллі установи природно-заповідного фонду вищого рангу - національного природного парку. Вперше для даного регіону вивчено ландшафтне різноманіття і здійснено комплексне середньомасштабне ландшафтне картографування. Розроблені карти детально ілюструють характер ландшафтної диференціації території і можуть слугувати базою для подальшого, більш детального фаціального картографування, використовуватись як основа для всіх подальших досліджень у районі розташування парку, а також для розроблення і реалізації природоохоронних заходів і програм, управління туризмом тощо. Одержані результати репрезентують внутрішні відмінності в межах району, з урахуванням яких можна розробити оптимальну структуру природокористування в межах досліджуваної території, зберегти і збільшити його ландшафтну різноманітність.

\section{Бібліографічні посилання}

Baranovskyi B. O., 2013. The current ecological state of the river basin Orel in the context of creating a national natural park «Priorilskyy» [Suchasnyi ekolohichnyi stan baseinu richky Oril v konteksti stvorennia natsionalnoho pryrodnoho parku «Pryorilskyi»] // Scientific Notes of Dnipropetrovsk State Agrarian and Economic University [Visnyk Dnipropetrovskoho derzhavnoho ahrarnoho universytetu]. - №2. - P. $55-60$. - Retrieved from URL: http://nbuv.gov.ua/UJRN/ vddau 2013 2_14 (in Ukrainian).

Belhard A. L., $19 \overline{4} 0$. Woods of Oril river valley [Lesa doliny r. Oreli // Proceedings of the Biological Faculty DSU [Zbirnyk prats biolohichnoho fakultety DDU]. - Dnepropetrovsk. - Vol. 3. (in Russian).

Chehorka P. T., 2003. Methods, content and results of the eco-tourism Association «Orlan» in the valley Orel [Metody, zmist i pidsumky roboty ekoloho-turystychnoho obiednannia "Orlan" v dolyni richky Oril] // Public participation in the conservation of small rivers of Ukraine [Uchast hromadskosti u zberezhenni malykh richok Ukrainy]. - K. - P. 56-57. (in Ukrainian).

Chehorka P. T., Maniuk V. V., Demianov V. V., Barsov V. O., Kochet V. I., Domrachev V. I., 2000. To the project of creation of Orilskyy National Park (environmental factors) [Do proektu stvorennia Orilskoho natsionalnoho pryrodnoho parku (ekolohichni chynnyky)] // National parks: problems of formation and development [Natsionalni pryrodni parky: problemy stanovlennia ta rozvytku].- Yaremche.- P. 351-357. (in Ukrainian). 
Demianov V. V., 2000. The current state of the river basin hydrological network [Suchasnyi stan hidrolohichnoi merezhi baseinu richky] // Problems of creation of Orilsky National Park. (Materials of scientific and pract. workshop, Dniprodzerzhynsk, Nov 16. 2000) [Problemy stvorennia Orilskoho natsionalnoho pryrodnoho parku. (Materialy nauk.-prakt. seminaru, Dniprodzerzhynsk, 16 lyst. 2000 r)]. - Dnipropetrovsk.- P. 12-14. (in Ukrainian).

Domrachev V., 2001. Orilskyy national park must be! [Orilskomu natsionalnomu parku - buty!] // Informational journalistic bulletin «Sviata Sprava» [Informatsiino-publitsystychnyi biuleten «Sviata Sprava»]. - № 1(4).- P.61. (in Ukrainian).

Kalinina P. F., Chugaj N. S., Bashmakov I. P., Malashenko T. D., 1971. On the question of the study of the morphological structure of landscapes Dnipropetrovsk region [K voprosu issledovaniya morfologicheskoj struktury landshaftov Dnepropetrovskoj oblasti] // Natural and human resources of left-bank Ukraine and their use : Mat. Interdepartmental third scientific conf. [Prirodnye i trudovye resursy Levoberezhnoj Ukrainy i ihispolzovanie : Mater. Tretej mezhved. nauch. konf.]. - Vol 10. - M.: Nedra. - P. 166 - 168. (in Russian).

Klevtsov T. A., 1960. Physic Geographical zoning of Dnipropetrovsk region [Fizyko-heohrafichne raionuvannia Dnipropetrovskoi oblasti] // Geographic collection. Vol. 4 (Geomorphological series) [Heohrafichnyi zbirnyk. Vyp. 4 (Heomorfolohichna seriia)]. - K. : Publishing House USSR Academy of Sciences. - P. 195-207. (in Ukrainian).

Maniuk V. V., 2000. Pryorillya as cell preservation of plant biodiversity of national importance [Pryorillia yak oseredok zberezhennia roslynnoho bioriznomanittia natsionalnoho znachennia] // Problems of creation of Orilsky National Park. (Materials of scientific and pract. workshop, Dniprodzerzhynsk, Nov 16. 2000) [Problemy stvorennia Orilskoho natsionalnoho pryrodnoho parku. (Materialy nauk.-prakt. seminaru, Dni- prodzerzhynsk, 16 lyst. 2000 r.)]. - Dnipropetrovsk.- P. 28-31. (in Ukrainian).

Maniuk V. V., 2010. Orilskyy national park: phenomenon, creating problems and prospects [Orilsky inatsionalnyi pryrodnyi park: fenomen, problemy stvorennia ta perspektyv] - Dnipropetrovsk. -21 p. (in Ukrainian).

National Atlas of Ukraine / ed. B.E. Paton. - K . : SSPE «Cartography», 2007. - 440 p. (in Ukrainian).

Shujdin S. V., 1998. On the question of landscape zoning of the territory of the Dnieper-Orelsky Nature Reserve [K voprosu o landshaftnom rajonirovanii territorii Dneprovsko-Orelskogo prirodnogo zapovednika] // Scientific Notes of Dnipropetrovsk National University [Visnyk Dnipropetr. un-tu. Heolohiia. Heohrafiia]. -Vol. 2. - Dnepropetrovsk : Publishing House DSU. P. 109 - 111. (in Russian).

The project of creation of the national park «Orilskyy.» In 6 volumes [Proekt stvorennia natsionalnoho pryrodnoho parku «Orilskyy». U 6 tomakh] / Authors, editedby V.V. Manyuk. - Vol.1. A comprehensive description of the national park «Orilskyy.» - Dnepropetrovsk. - 411 p. (in Ukrainian).

Yeliashevych O. A., 1937. Orilskyy grasslands [Orilski luky] // Proceedings of the Botanical Garden of Dnepropetrovsk [Zbirnyk prats Dnipropetrovskoho botanichnoho sadu]. - Dnepropetrovsk: Publishing House DSU. - № 2. - P. 3-34. (in Ukrainian).

Zelenska L. I., Afanasiev O. Y., Maniuk V. V., Solohub T. P., 2009. Development of the zoning scheme of the projected national park «Orilskyy» territory in order to optimize the structure environmental management [Rozrobka skhemy zonuvannia chastyny terytorii proektovanoho natsionalnoho pryrodnoho parku «Orilskyi» z metoiu optymizatsii struktury pryrodokorystuvannia] // Scientific Notes of Dnipropetrovsk National University [Visnyk Dnipropetr. un-tu. Heolohiia. Heohrafiia]. - Vol.17. - №3/2. - Pub.11. - P. 50 - 60. (in Ukrainian).

Надійшла до редколегії 12.10.2016 